\title{
State Capacity and Public Trust in Handling the COVID-19 Outbreak in Malaysia
}

\author{
Kapasitas Negara dan Kepercayaan Publik \\ dalam Penanganan Wabah Covid-19 di \\ Malaysia
}

\author{
Suyatno Ladiqi \\ Universiti Sultan Zainal Abidin, Malaysia
}

\begin{abstract}
ABSTRAK
Respons negara-negara terhadap pandemi global sangatlah beragam. Kebijakan yang diambil pemerintah dan dukungan dari masyarakat sangat menentukan keberhasilan penanganan pandemi tersebut. Ada beberapa negara yang cukup lama berjuang melawannya sehingga memiliki implikasi ekonomi yang serius. Tetapi, ada juga negara yang secara efisien mengatasinya sehingga mampu menghambat melonjaknya jumlah penderita Covid-19 dan melindungi ekonomi negaranya. Selain Selandia Baru, Taiwan dan China, Malaysia termasuk salah satu negara yang memiliki kapasitas cukup baik dalam penanganan pandemi Covid-19 dalam bentuk kemampuan menekan penyebaranvirus dan menormalkan kembaliperekonomiannya. Artikel ini menjelaskan bagaimana kapasitas negara mampu menjadi modal besar dalam penanganan pandemi di Malaysia. Kapasitas negara yang memadai akan mampu menimbulkan kepercayaan publik sehingga kepercayaan itu dapat menjadi katalisator bagi berhasilnya pelaksanaan kebijakan. Selain kapasitas negara, aspek kepemimpinan di level nasional dan level lokal berperan penting dalam mendukung keberhasilan kebijakan pemerintah. Kepemimpinan yang efektif dapat mendorong suasana kondusif bagi ketaatan masyarakat untuk menaati kebijakan pemerintah. Ibarat musuh bersama (common enemy), dukungan elemen masyarakat sangat diperlukan bagi keberhasilan melawan penyebaran virus.
\end{abstract}

Kata-kata kunci: Malaysia, kapasitas negara, kepercayaan publik

Countries' responses to global pandemic have been mixed. The policies taken by the government and the support of the community will significantly determine the success of handling the pandemic. Several countries have struggled against it for a long time to have profound economic implications, but some countries have efficiently dealt with it to prevent the increasing number of Covid-19 sufferers and protect the country's economy. Apart from New Zealand, Taiwan and China, Malaysia is one of the countries that have adequate capacity to handle the Covid-19 pandemic in the form of the ability to suppress the spread of the virus and normalize its economy again. This paper explains how the country's capacity can become a significant capital in handling pandemic in Malaysia. Adequate state capacity will generate public trust so that this trust can be a catalyst for the successful implementation of policies. Apart from the state's capacity, the leadership aspect at the national and local levels plays a vital role in supporting the success of government policies. Effective leadership can encourage a conducive atmosphere for community obedience to comply with government policies. Like a common enemy, the support of social elements is necessary for the success against the spread of the virus.

Keywords: Malaysia, state capacity, public trust 
Virus Corona atau yang lebih popular dikenal sebagai Covid-19 diketahui sebagai virus yang pertama kali melanda kota Wuhan, China. Pada akhirnya virus ini melanda seluruh dunia tanpa terkecuali termasuk Malaysia. Negara dengan sistem kesehatan yang canggih seperti China, Amerika Serikat, Jepang, dan negaranegara di Eropa Barat tak terkecuali juga terkena serangan wabah Covid-19. Virus yang mampu membunuh manusia ini sudah terbukti memakan korban di banyak negara, yaitu lebih 800 ribu orang meninggal dunia di seluruh dunia (Worldometers 2020).

Kehadiran negara dalam studi ilmu politik sangat penting untuk diperhatikan, terutama ketika isu demokratisasi menjadi isu global. Demokratisasi berarti mengurangi peranan negara secara signifikan dan digantikan oleh rezim yang demokratis. Ada peralihan kuasa dari yang tertutup (otoriter) menuju pengelolaan kekuasaan yang lebih terbuka dengan melibatkan peranan rakyat, yang dikenal sebagai Transisi menuju Demokrasi. Huntington (1993) mengistilahkan transisi menuju demokrasi itu sebagai "gelombang demokratisasi". Sebagai gelombang, perkembangan politik yang meminggirkan peran negara dan menggantikannya dengan peran dominan rakyat diawali pada gelombang pertama, ketika Revolusi Amerika yang diilhami oleh Revolusi Perancis seolah menjadi arus deras yang tidak bisa dihindari. Peran negara tidak lagi mutlak sebagaimana sebelumnya ini berlaku yang termanifestasi dalam diri seorang pemimpin mutlak (Raja) saja, tetapi peranannya harus dibagi dengan wakil-wakil rakyat. Gelombang Kedua ditandai oleh berakhirnya Perang Dunia kedua yang mana negara-negara Barat ramai-ramai mengusung demokrasi dan memaksakan sistem demokrasi kepada negara yang kalah perang (Jerman dan Jepang). Runtuhnya rezim otoriter di negara-negara berkembang di Amerika Latin dan Amerika Tengah serta Eropa Timur dan Asia Timur menandai Gelombang Demokratisasi Ketiga yaitu pada tahun 1980-and dan tahun 1990-an (Huntington 1993; Diamond 1997; Reilly 2012).

\section{Kapasitas Negara, Kepercayaan Publik, dan Kepemimpinan}

Pada perkembangannya, di satu sisi, pengurangan peran 
negara otoriter menjadi trend global. Ruang untuk rakyat turut memainkan peranan dalam dinamika suatu negara, menjadi pilihan yang terus meningkat. Kini hanya Korea Utara dan Kuba yang masih memainkan peranan negara secara otoriter dalam diri pemimpin ataupun dalam manifestasi partai politik Komunis. Cina pun meski masih mengontrol politik negara, tetapi menjalankan liberalisasi ekonomi. Di sisi lain, negara-negara yang meski sudah mendemokratisasikan dirinya ternyata dalam perjalanannya banyak mengalami kegagalan. Afghanistan, Irak, Somalia, Haiti, Timor-Leste, Sierra Leone dan Liberia adalah contoh negara gagal yang meski juga menjalankan proses demokratisasi, tetapi proses pelembagaan yang lemah menjadikan lahirnya negara lemah (weak state). Idealnya negara tetap hadir, tetapi bukan dalam wajah otoriter melainkan dalam wajah negara kuat (strong state) yang memiliki kemampuan menciptakan masyarakat yang stabil, damai, sejahtera, inklusif, dan jujur. Adapun syarat yang harus dipenuhi oleh 'strong state' adalah adanya kemampuan mengelola negara secara modern dan kokoh (modern and strong state), memiliki kapasitas menegakkan hukum dengan baik (rule of law) dan mampu menciptakan akuntabilitas (Fukuyama 2014). Melemahnya unsur-unsur penting tersebut pada akhirnya akan menggerus derajat demokrasi dan pada gilirannya melemahkan kapasitas negara.

Inilah yang menjelaskan ketika negara mengalami serangan wabah penyakit yang bisa diibaratkan sebagai ancaman nontradisional, maka 'negara kuat' dalam pandangan Fukuyama menjadi teramat penting peranannya. Musuh yang masuk ke dalam negara tanpa terlihat dalam bentuk virus adalah bukan hal yang mudah dihadapi oleh negara manapun. Tidak seperti hadirnya tentara musuh yang masuk melintas perbatasan suatu negara yang dapat dilihat secara kasat mata. Francis Fukuyama (2020) menyebut terdapat 3 (tiga) aspek penting ketika negara harus hadir menyelamatkan warganya dari serangan pandemi. Aspekaspek itu adalah kapasitas negara (state capacity), kepercayaan publik (social trust) dan kepemimpinan (leadership). Negara yang memiliki pemerintahan yang kompeten sehingga kebijakannya dirasakan mengayomi dan menguntungkan warganya, tentu akan melahirkan kepercayaan publik dan pada masa yang sama kepemimpinan yang efektif dalam mengkomunikasikan kebijakan 
serta sukses memberi teladan akan menjadi sinergi yang efektif dalam memerangi pandemi.

Pada kasus pandemi global Covid-19, Fukuyama melihat pentingnya unsur-unsur tersebut karena menentukan kejayaan negara dalam penanganan pandemi. Amerika Serikat dijadikan contoh betapa lemahnya kepemimpinan Trump dalam menangani pandemi. Alih-alih menjadikan Covid-19 sebagai fokus persoalan, Trump justru membuat polarisasi yang memecah belah masyarakatnya. Misalnya sebagian masyarakat ikut menyalahkan Covid-19 sebagai 'China-flu' atau "Kung-flu' yang bertendensi rasisme sebagaimana disampaikan dalam pidato Trump (Washington Post, 2020). Akibatnya kapasitas negara Amerika Serikat yang selama ini teruji cukup tangguh, khususnya dalam penanganan epidemi sebelumnya, ketika berhadapan dengan pandemi Covid-19 seolah-olah runtuh dan kurang mendapat 'social trust' dari masyarakat (Fukuyama 2020). Polarisasi masyarakat memperburuk citra Amerika sebagai negara nomor terbanyak warganya yang menderita Covid-19, yaitu lebih 5 juta penderita Covid-19 dan lebih dari 170 ribu orang yang meninggal dunia (Worldometer 2020).

Untuk keperluan artikel ini, penulis mencoba menggunakan konsepsi Fukuyama tersebut dalam menjelaskan kasus Covid-19 di Malaysia. Nampak jelas bahwa pemerintah Malaysia merespons serangan pandemi Covid-19 dengan mengeluarkan berbagai kebijakan yang disertai kepemimpinan yang kompeten dari elit politiknya sehingga mendapat respons positif dari warganya. Sinergi yang luar biasa ini menjadikan Malaysia sebagai negara yang berhasil dalam menangani pandemi Covid-19.

\section{Dari Perintah Kawalan Pergerakan (PKP) ke Perintah Kawalan Pergerakan Pemulihan (PKPP)}

Kasus pertama kali Covid-19 muncul di Malaysia muncul pada tanggal 24 Januari 2020, ketika Kementerian Kesihatan Malaysia (KKM) mengumumkan bahwa terdapat penderita Covid-19 yang memiliki hubungan kekerabatan dengan keluarga mereka di Wuhan, China (Malaysiakini, 2020). Lambat laun Covid-19 
mulai menyerang berbagai negara bagian, tanpa disadari tingkat bahayanya. Kondisi ini mendorong World Health Organization (WHO) untuk menyatakan bahwa virus corona sebagai pandemi global pada 11 Maret 2020, dengan mempopulerkan istilahnya sekaligus yaitu coronavirus diseases dengan sebutan "Covid-19". Pandemi adalah wabah penyakit menular berskala besar yang dapat meningkatkan morbiditas (skala perluasan penyakit) dan mortalitas (skala kematian) di wilayah geografis yang luas dan menyebabkan gangguan ekonomi, sosial, dan politik yang signifikan (WHO 2020).

Kasus pertama kematian di Malaysia terjadi pada tanggal 17 Maret 2020, ketika seorang pastor berusia 60 tahun di Sarawak meninggal dunia akibat Covid-19 sebagaimana diumumkan oleh Jawatankuasa Pengurusan Bencana Negeri Sarawak. Pada waktu yang sama, KKM juga menyatakan terdapat 673 kasus Covid-19, dua pertiganya berasal dari acara keagamaan Jamaah Tablig di Masjid Jameek, Kuala Lumpur yang diselenggarakan pada tanggal 27 Februari hingga 1 Maret 2020. Tak kurang dari 16.00o orang menghadiri acara tersebut dan 1.500 orang diantaranya berasal dari luar negeri (Ananthalakshmi dan Sipalan 2020). Inilah kasus yang dianggap sebagai pemicu meledaknya pandemi Covid-19 di wilayah Asia Tenggara (Barker 2020).

Sehari sebelumnya pemerintah sebenarnya sudah merespons dengan mengeluarkan kebijakan yang akan dijalankan pada 18 Maret 2020, yang dikenal dengan nama Perintah Pergerakan Kawalan (PKP) Malaysia 2020 (Bunyan, 2020). Langkah ini bertujuan untuk mencegah lebih luas rakyat dijangkiti Covid-19, serta memberi ruang kepada pemerintah melakukan usaha pemulihan secepat mungkin. Kebijakan ini merangkumi larangan-larangan yang harus dipatuhi oleh rakyat Malaysia, yaitu: (1) larangan menyeluruh mobilitas dan perhimpunan massa di seluruh negara termasuk aktivitas keagamaan, olah raga, sosial dan budaya. Semua rumah ibadat dan dunia usaha, kecuali supermarket, pasar tradisional, dan toko kelontong yang menjual aneka sembako masih diizinkan beroperasi. Bagi umat Islam, semua kegiatan keagamaan di masjid dan surau termasuk Salat Jumat juga dibatalkan; (2) pembatasan menyeluruh semua perjalanan rakyat Malaysia ke luar negeri, dan juga bagi 
mereka yang baru pulang dari luar negeri diwajibkan menjalani pemeriksaan kesehatan dan melakukan karantina secara sukarela selama 14 hari; (3) pembatasan semua wisatawan asing dan orangorang asing dalam urusan apapun ke Malaysia; (4) penutupan semua sekolah di berbagai tingkat, baik sekolah negeri maupun sekolah swasta; (5) penutupan semua kegiatan pendidikan di tingkat universitas dan akademi di seluruh negara; dan (6) penutupan semua kantor pemerintah dan kantor swasta, kecuali kantor yang terlibat dengan pelayanan masyarakat yang penting kesehariannya yaitu kantor urusan air, listrik, telekomunikasi, pos, transportasi, pengairan, minyak, gas, penyiaran, keuangan, perbankan, kesehatan, farmasi, pemadam kebakaran, penjara, pelabuhan, lapangan terbang, keselamatan, pertahanan, pembersihan, sektor usaha di bidang sembako.

Kebijakan ini pada awalnya berlangsung mulai 18 Maret hingga 31 Maret 2020 (Awani.com 2020) tetapi dilanjutkan hingga 14 April sebagai usaha untuk menekan penularan COVID-19 di seluruh negara (Tee 2020). Pemerintah Malaysia memberikan legitimasi hukum bahwa kebijakan PKP dilakukan berdasarkan Akta Pencegahan dan Pengawalan Penyakit Berjangkit 1988 dan Akta Polis 1967. Legitimasi hukum ini banyak dilihat oleh berbagai kalangan sebagai kebijakan yang kokoh dan mampu menghindarkan diri dari perdebatan hukum. Sehingga siapapun orangnya yang melanggar ketentuan larangan mobilitas atau pergerakan fisik misalnya, akan dihukum denda sebanyak RM1,000 atau Rp. 3,5 juta dan/atau penjara 6 bulan. Tentara diturunkan ke jalan-jalan membantu polisi untuk menjalankan kebijakan tersebut (Azyyati, 2020).

Selain melarang orang keluar rumah kecuali untuk urusan membeli kebutuhan rumah tangga, itu pun hanya boleh dilakukan oleh salah seorang wakil, PKP juga secara spesifik sejak 1 April 2020 menerapkan kebijakan tambahan. PKP melarang seseorang menemani orang lain di jalan raya, kecuali dengan tujuan untuk berobat, itu pun radius perjalanan dibatasi sejauh $10 \mathrm{~km}$ dan melarang semua jenis kegiatan massal, kecuali untuk acara pemakaman jenazah dengan jumlah pelayat yang dibatasi dan dilakukan seizin kepolisian setempat. 


\section{Suyatno Ladiqi}

Pada masa pelaksanaan PKP ada kebijakan khusus yang dijalankan di sebagian daerah di Malaysia. Hal ini terjadi karena daerah tersebut dianggap tingkat penularannya tinggi. Kebijakan khusus tersebut dikenal dengan sebutan Perintah Kawalan Pergerakan Diperketatkan (PKPD) yang dijalankan selama 14 hari yang mencakup wilayah tertentu di Kuala Lumpur, Selangor dan Johor. Kebijakan pelarangan terhadap wilayah yang ditetapkan yaitu: (1) semua penduduk dan pengunjung di dalam wilayah dilarang keluar dari rumah mereka; (2) bukan penduduk dan pengunjung dari luar wilayah tidak dibenarkan masuk ke wilayah yang ditetapkan; (3) semua kegiatan usaha ditutup; sembako yang mencukupi akan diberikan oleh pemerintah selama 14 hari untuk semua penduduk; (4) pusat Kesehatan atau klinik akan didirikan di wilayah itu; dan (5) semua jalan ke wilayah itu dijaga oleh polisi dan tentara (Nursyazwani 2020).

Pada tanggal 1 Mei 2020, Perdana Menteri Malaysia, Tan Sri Muhyiddin Yassin dalam pidato resminya ketika merayakan Hari Buruh telah mengenalkan kebijakan lanjutan yaitu Perintah Kawalan Pergerakan Bersyarat (PKPB). Kebijakan ini merupakan bentuk pelonggaran dari pelaksanaan kebijakan PKP dengan tujuan membuka kegiatan ekonomi negara meski tetap dalam kontrol yang ketat. Hal ini dilakukan ketika tingkat penularan dan penyebaran Covid-19 mulai bisa dikendalikan secara efektif. Syarat-syarat baru dalam PKPB termasuk: (1) hampir semua sektor dan kegiatan ekonomi diizinkan beroperasi sambil tetap memperhatikan prosedur operasi standar (SOP) perniagaan yang mencakup penjarakan sosial dan mencatat nama dan nomor telefon pelanggan dan tanggal kunjungan; (2) tidak dibenarkan melakukan kegiatan olahraga yang melibatkan massa besar, adanya sentuhan badan dan risiko penularan, termasuk semua acara olahraga di dalam gedung (indoor) maupun dalam stadion (outdoor). Kegiatan olah raga yang tidak dilarang dengan syarat dilakukan tanpa penonton dan tidak melebihi 10 orang; (3) acara sosial, kemasyarakatan dan budaya yang melibatkan massa besar serta semua jenis acara dan perhimpunan resmi adalah tidak dibenarkan. Kegiatan keagamaan dan semua kegiatan berjamaah atau perhimpunan di rumah ibadah juga tidak dibenarkan; dan (4) perjalanan antara provinsi (negeri), termasuk tradisi pulang kampung pada hari Lebaran juga tidak dibenarkan, kecuali untuk 
tujuan kerja dan pulang akibat tertahan di kampung halaman atau di tempat lain setelah mendapat izin kepolisian daerah (Bernama 2020).

Perkembangan penanganan Covid-19 di Malaysia tergolong sukses, terbukti dengan pelonggaran yang makin luas dalam bentuk kebijakan Perintah Kawalan Pergerakan Pemulihan (PKPP) yang menggantikan PKPB yang berlaku mulai 10 Juni hingga 31 Agustus. Kebijakan ini lebih banyak memberi kelonggaran kepada rakyat untuk menjalankan kegiatan harian sambil mematuhi prosedur operasi standar (SOP). Ada beberapa kegiatan yang masih dilarang yaitu kegiatan olah raga yang melibatkan massa besar, kegiatan dunia hiburan (karaoke, pub dan tempat pijat), kegiatan keagamaan yang melibatkan massa, dan wisata ke luar negeri (myMetro 2020).

Dinamika pelaksanaan kebijakan PKP hingga ke PKPP adalah wujud respons pemerintah terhadap tingkat penularan Covid-19 di dalam negeri. Grafik di bawah ini menggambarkan secara jelas naik turun Covid-19 di Malaysia sangat mempengaruhi kebijakan yang ditetapkan oleh pemerintah. Tingkat pertambahan kasus bisa dikontrol secara minimal dan disertai tingkat kesembuhan penderita terus meningkat serta tingkat kematian bisa ditekan seminimal mungkin. 


\section{Grafik 1}

\section{Perkembangan Kasus Harian Covid-19 di Malaysia}

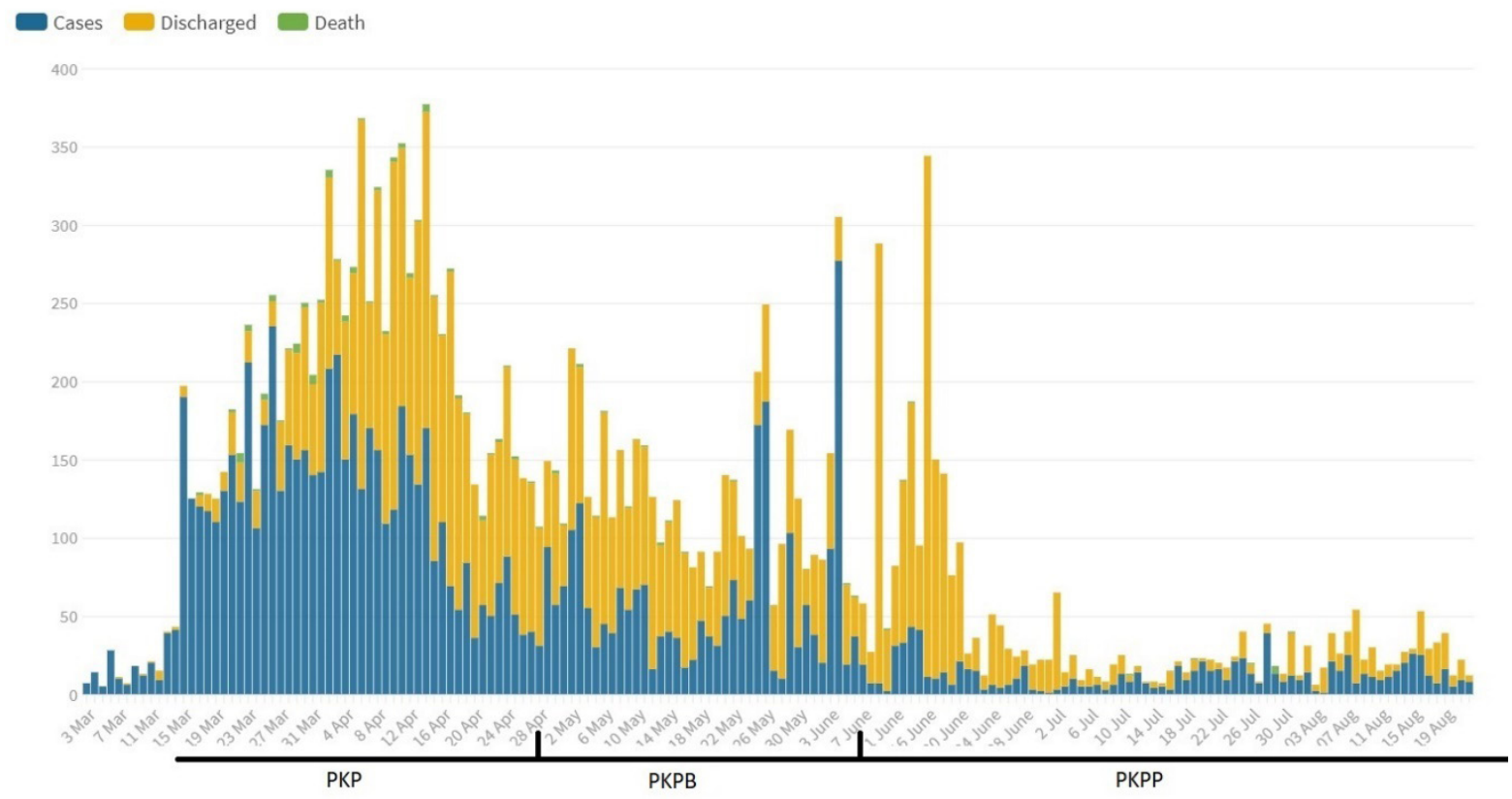

Sumber: Berita Harian Online (2020)

Penanganan Covid-19 Malaysia tergolong sangat baik ketika keseluruhan kasus yang ada bisa disertai dengan tingkat kesembuhan yang tinggi. Dari data sementara hingga 22 Agustus 2020, jumlah keseluruhan penderita Covid-19 di Malaysia adalah sebanyak 9.265 orang. Jumlah penderita yang berhasil disembuhkan (discharge) sebanyak 8.953 orang, ini berarti tingkat kesembuhannya mencapai $96.75 \%$. Adapun kasus kematian (death) berjumlah 125 orang dan penderita yang masih memerlukan waktu untuk penyembuhan sebanyak 183 orang (KKM, 2020). Keberhasilan ini tentu tidak lain dari kebijakan PKP yang dijalankan bisa direspons dengan baik oleh rakyat Malaysia. Hal ini disebabkan karena kapasitas negara Malaysia dan ketaatan warga untuk menjalani larangan-larangan yang ditetapkan. 
State Capacity and Public Trust

in Handling the COVID-19 Outbreak in Malaysia

\section{Paket Bantuan Prihatin Nasional dan Penegakan Hukum}

Untuk mendukung kebijakan pelarangan mobilitas warga (PKP), pemerintah Malaysia menyadari bahwa ekonomi lokal tentu akan sangat terganggu, untuk itu diperlukan bantuan ekonomi, terutama bantuan kepada golongan masyarakat yang berpenghasilan rendah. Pemerintah mengeluarkan kebijakan Paket Rangsangan Ekonomi Prihatin Rakyat (Prihatin) untuk mengatasi masalah tersebut, selain bantuan tunai langsung penambahan pengadaan peralatan dan jumlah tenaga medis juga dilakukan, sebagai garda terdepan pembendungan penularan COVID-19. Kebijakan yang lain adalah penyediaan dana dan dukungan keuangan kepada pelaku usaha kecil dan menengah (Kementerian Kewangan Malaysia 2020).

Tujuan utama Paket Prihatin adalah: (1) melindungi rakyat; (2) dukungan dunia usaha; dan (3) memperkukuh ekonomi. Keseluruhan dana yang disediakan adalah RM250 milyar yang penyalurannya dibagi dalam beberapa sektor yaitu RM128 milyar untuk sektor kesejahteraan rakyat dalam bentuk bantuan tunai langsung, RM10o untuk mendukung dunia usaha kecil dan menengah, RM2 milyar untuk memperkukuh ekonomi negara dan RM2O milyar merupakan kelanjutan program bantuan pemerintah sebelum pandemi (Kementerian Kewangan Malaysia 2020).

Kebijakan ini memang boleh dikatakan menyentuh seluruh elemen masyarakat. Insentif yang diberikan dalam bentuk penambahan jumlah tunjangan gaji cukup berarti. Untuk garda terdepan Covid-19 seperti perawat, dokter dan tenaga medis, tunjangan yang semula didapat sebesar RM400 dinaikkan menjadi RM600 tiap bulannya. Pemerintah juga menambah tunjangan khusus sebesar RM20o tiap bulannya kepada setiap anggota tentara, polisi, bea cukai, imigrasi, pemadam kebakaran, anggota Angkatan Pertahanan Awam serta anggota RELA (sukarelawan) yang terlibat secara langsung dalam melaksanakan PKP. Tunjangan-tunjangan tersebut dibayarkan mulai 1 April 2020 hingga pandemi COVID-19 berakhir.

Sementara itu pada level masyarakat awam, khususnya masyarakat yang berpenghasilan rendah, yang diistilahkan dengan sebutan 
golongan M40, yaitu mereka yang memiliki penghasilan di bawah RM4 ribu/bulan, pemerintah menyediakan kebijakan Bantuan Prihatin Nasional yaitu pemberian bantuan tunai secara oneoff dengan anggaran mencapai hampir RM10 milyar dan untuk pertama kalinya akan disalurkan. Golongan lain yang dikategorikan mendapat bantuan ini termasuk pekerja swasta, pekerja FELDA (Federal Land Development Authority), petani, nelayan, pelaku usaha kecil dan semua yang tergolong dalam golongan M40 dan ke bawah. Besaran tunjangan yang diberikan dapat dicek melalui tabel di bawah ini.

Tabel 1

Pembayaran Bantuan Prihatin Nasional

\begin{tabular}{|c|c|c|c|c|}
\hline No. & Penerima & $\begin{array}{l}\text { April } \\
2020\end{array}$ & $\begin{array}{l}\text { Mei } \\
2020\end{array}$ & Jumlah \\
\hline 1. & $\begin{array}{l}\text { Rumah tangga berpenghasilan } \leq \mathrm{RM} 4,000 \\
\text { sebulan ( } 4 \text { juta rumah tangga) }\end{array}$ & RM1,00o & RM60o & RM1,60o \\
\hline 2. & $\begin{array}{l}\text { Rumah Tangga berpenghasilan } \mathrm{RM}_{4,001-} \\
\text { RM8,ooo sebulan (1.1 juta rumah tangga) }\end{array}$ & RM500 & RM5O0 & RM1,ooo \\
\hline 3. & $\begin{array}{l}\text { Individu bujangan berpenghasilan } \\
\leq \mathrm{RM} 2, \text { ooo sebulan ( } 3 \text { juta individu } \\
\text { berumur } \geq 21 \text { tahun) }\end{array}$ & RM5Oo & RM300 & RM80o \\
\hline 4. & $\begin{array}{l}\text { Individu bujangan berpenghasilan } \\
\mathrm{RM} 2,001-\mathrm{RM} 4, \text { ooo sebulan ( } 400,000 \\
\text { individu berumur } \geq 21 \text { tahun) }\end{array}$ & RM250 & RM250 & $\mathrm{RM}_{500}$ \\
\hline
\end{tabular}

Sumber: Kementerian Kewangan Malaysia (2020)

Pemerintahjuga memberikan bantuankepadagolongan mahasiswa dengan bantuan tunai langsung secara one-off sebanyak RM200 tiap orang yang dibayar pada bulan Mei 2020. Dana sebesar RM25 juta juga disalurkan untuk membantu golongan warga lansia, anakanak pantai asuhan, penyandang disabilitas, gelandangan dan orang pribumi pedalaman. Penyalurannya dilakukan berdasarkan kerjasama antara pemerintah dan Lembaga Swadaya Masyarakat (LSM) serta sukarelawan sosial dalam bentuk penyaluran bantuan makanan, peralatan medis dan tempat perlindungan untuk mereka. Di sektor perbankan dan keuangan, pemerintah juga memberikan penangguhan pembayaran kredit selama enam 
bulan. Adapun golongan M40 yang dimasukkan ke rumah sakit karena tertular Covid-19, pemerintah memberikan bayaran RM5O per harinya untuk masa maksimum 14 hari.

Di sektor telekomunikasi pemerintah juga memberikan bantuan kepada seluruh rakyat untuk mendapatkan internet gratis hingga PKP berakhir. Listrik juga diberi diskon hingga 50\% kepada pelanggan. Adapun pegawai negeri yang berjumlah 1,5 orang di seluruh juga mendapatkan bantuan tunai langsung secara one-off sebesar RM500 tiap orang. Para pensiunan yang berjumlah 850 ribu orang juga mendapat bantuan tunai langsung secara oneoff sebesar RM500 per orang (Kementerian Kewangan Malaysia 2020).

Kebijakan Paket Prihatin juga menyasar keseluruhan sektor yang lain yang terdampak Covid-19. Paling tidak kebijakan ini menggambarkan betapa kapasitas negara mampu melindungi rakyat yang terdampak dan perlindungan ini dirasakan oleh seluruh elemen rakyat. Secara keseluruhannya, Paket PRIHATIN ini telah banyak menolong meringankan beban rakyat yang terdampak COVID-19, terutama golongan rakyat berpenghasilan rendah dan sektor usaha kecil menengah. Melalui pelaksanaan kebijakan ini, pemerintah Malaysia meyakini bahwa pandemi dapat dibendung sepenuhnya dan kesejahteraan hidup rakyat dapat dikembalikan seperti semula.

Ibarat stick and carrot, disamping diberikan serangkaian bantuan yang meringankan beban, pemerintah juga menegakkan hukum untuk menjaga efektivitas kebijakan berjalan dengan baik yaitu dengan menghukum rakyat yang melanggar peraturan yang sudah diumumkan. Selama pelaksanaan PKP sebanyak 11,295 orang ditahan karena melanggar aturan PKP. Sebanyak 5,930 orang dituntut di pengadilan (Affendy 2020). Sedangkan pada masa PKPB total orang yang ditahan 26.366 orang, yang mana 20.720 orang dibawa ke pengadilan. Kesalahan yang paling banyak dilakukan yaitu melanggar aturan larangan saling berkunjung pada masa Hari Raya Idul Fitri. Namun begitu ada juga jenis kesalahan yang dilakukan karena menghalangi petugas di lapangan semasa PKP. Misalnya kasus seorang mekanik berusia 33 tahun didakwa di Pengadilan Magistrat Sungai Siput dengan kasus serupa. Mekanik tersebut mengaku bersalah dan 
dijatuhi hukuman denda RM5 ribu, jika gagal membayar, maka diharuskan menghabiskan di penjara selama 10 bulan (MalayMail 2020). Contoh yang lain adalah 7 (tujuh) pria dijatuhi hukuman denda masing-masing RM1.00o, dengan tiga bulan pengabdian masyarakat karena bermain sepak bola dan jogging di lapangan di Pulau Tikus, Penang (Trisha dkk. 2020).

Penegakan hukum juga berlaku kepada elit politik dan ini menjadikan unsur kepemimpinan memberikan teladan semakin mengukuhkan tingkat kepercayaan publik. Contoh kasus adalah ketika Perdana Menteri Muhyiddin Yassin harus mengkarantina dirinya sendiri selama 14 hari. Hal tersebut dilakukan karena ada salah satu perwira yang datang menemui beliau positif terjangkit Covid-19. Meski hasil tes menunjukkan negatif, tetapi tetap harus melakukan karantina mandiri menurut Perintah Pengawasan dan Pengamatan untuk Kontak Covid-19 (Bagian 15 (1) UU 342) (Warta Ekonomi 2020). Disebutkan juga bahwa semua pejabat dan pegawai yang hadir dalam rapat yang sama juga diminta melakukan pemeriksaan dan menjalani karantina mandiri selama dua pekan. Beberapa pejabat yang hadir antara lain Kepala Sekretaris Pemerintah Malaysia, Mohd Zuki Ali dan Ketua Komisi Antikorupsi Malaysia, Azam Baki (Detiknews 2020).

Menarik untuk dikemukakan ketika oposisi Malaysia bisa menahan diri untuk tidak melanjutkan kegaduhan politik. Sebulan sebelum penerapan PKP, Mahathir Mohammad meletakkan jabatannya sebagai Perdana Menteri. Kegaduhan politik pada akhirnya mereda setelah Yang Dipertuan Agong Malaysia menetapkan Muhyiddin Yassin berdasarkan proposal yang ditawarkan oleh mayoritas anggota parlemen Malaysia. Pemimpin oposisi, Anwar Ibrahim, memang sempat mempertanyakan dana untuk Paket Prihatin Nasional, agar pelaksanaannya terhindar dari kebocoran (Husain 2020). Namun begitu kegaduhan politik tidak sempat terjadi karena fokus Malaysia terhadap penanggulangan Covid-19 lebih dominan. Pemerintah sudah menjawab alasan kondisi darurat sehingga kebijakan itu diambil dan belum perlu dipresentasikan lebih jauh di parlemen. Pemerintah juga memastikan semua kebijakan ditetapkan diatas hukum yang berlaku di Malaysia (Rosly 2020). 
State Capacity and Public Trust

in Handling the COVID-19 Outbreak in Malaysia

\section{Simpulan}

Malaysia berhasil meyakinkan rakyatnya terlindungi dari dampak Covid-19 ketika diminta untuk tidak keluar rumah pada masa tertentu demi menghindarkan diri dari ancaman penularan virus. Kebijakan PKP, PKPB dan PKPP disertai dengan dukungan finansial yang mencukupi dan keterjangkauannya yang mampu menyentuh seluruh elemen masyarakat, menjadi modal penting untuk melawan Covid-19. Ini bentuk kapasitas negara yang mumpuni, sehingga rakyat merasa sudah selayaknya memberikan kepercayaan (trust). Di satu sisi sudah semestinya menghindarkan diri dari penularan Covid-19 dengan tidak keluar rumah, tetapi di sisi lain sumber ekonomi yang tersumbat karena mobilitas dibatasi ternyata mendapatkan gantinya melalui kebijakan Bantuan Prihatin Nasional. Apatah lagi penegakan hukum juga dilakukan sehingga pelembagaan taat hukum dan kepercayaan publik bisa dibangun dengan efektif. Belum lagi elit politik menunjukkan sikap kepemimpinan yang pantas diteladani ketika merespons dampak pandemi tersebut. Kombinasi ketiga aspek tersebut, yaitu kapasitas negara, kepercayaan publik dan kepemimpinan di Malaysia boleh dikatakan berhasil dalam menangani penularan Covid-19. Hal ini bisa dilihat dari penurunan jumlah penderita Covid-19, rendahnya tingkat kematian dan tingginya tingkat kesembuhan, serta kembalinya ekonomi lokal menjadi pertanda bahwa terdapat efektivitas dari pelaksanaan kebijakan PKP di Malaysia.

\section{Referensi}

\section{Buku dan Bab dalam Buku}

Fukuyama, Francis. 2014. Political Order and Political Decay: From the Industrial Revolution to the Globalization of Democracy. Farrar, Straus, and Giroux.

Huntington, Samuel P. 1993. The third wave: Democratization in the late twentieth century. Oklahoma Press. 


\section{Jurnal dan Jurnal Daring}

Diamond, Larry Jay. 1996. "Is the Third Wave Over?”, Journal of Democracy, 7 (3): 20-37.

Reilly, B. 2012. "Asia's Surprising Democratic Renaissance. Review Democracy's.Third Wave: Lessons and Legacies”. World Politics.

\section{Artikel Daring}

Affendy, Safeek, 2020 "Jumlah tangkapan PKP Fasa 2 meningkat 7,668 individu”. Berita Harian Online, Rabu, 15 April 2020 [daring] https://www.bharian.com.my/berita/ nasional/2020/04/677482/jumlah-tangkapan-pkpfasa-2-meningkat-7668-individu. [diakses pada 18 Agustus 2020].

Ahmad, Azyyati, 2020. "Movement Control Order gazetted: punishment of 6 months in prison, additions regarding important sectors". Astro Awani, 18 Maret 2020. [daring] http://english.astroawani.com/malaysia-news/6months-imprisonment-violating-movement-controlorder-234136. [diakses pada 18 Agustus 2020].

Ananthalakshmi, A. dan Sipalan, Joseph. 2020. "How Mass Pilgrimage at Malaysian Mosque Became Coronavirus Hotspot". Reuters. 17 March 2020. [daring] https://www. reuters.com/article/us-health-coronavirus-malaysiamosque/how-mass-pilgrimage-at-malaysian-mosquebecame-coronavirus-hotspot-idUSKBN2142S4. [diakses pada 10 Agustus 2020].

Awani, 2020, "Ucapan penuh: Perutusan Khas Perdana Menteri mengenai COVID-19". Astro Awani, 16 Maret 2020. [daring] https://www.astroawani.com/berita-malaysia/ 
State Capacity and Public Trust

in Handling the COVID-19 Outbreak in Malaysia

ucapan-penuh-perutusan-khas-perdana-menterimengenai-covid19-233916. [diakses pada 16 Agustus 2020].

Barker, Anne, 2020. "Coronavirus COVID-19 cases spiked across Asia after a mass gathering in Malaysia. This is how it caught the countries by surprise". ABC News, 19 Mac 2020. [daring] https://www.abc.net.au/news/2020-03-19/ coronavirus-spread-from-malaysian-event-to-multiplecountries/12066092. [diakses pada 10 Agustus 2020].

Berita Harian Online, "Peningkatan Harian dalam Kes". 16 Maret 2020, [daring] https://www.bharian.com.my/covid-19/ index.html. [diakses pada 22 Agustus 2020].

Bernama. 2020."Perintah Kawalan Pergerakan bersyarat akan dilaksana - Muhyiddin". Bernama. 1 Mei 2020. [daring] https://www.bernama.com/bm/am/news. php?id=1837419. [diakses pada 16 Agustus 2020].

Bunyan, John. 2020. "PM: Malaysia under movement control order from Wed until March 31, all shops closed except for essential services". The Malay Mail, 16 March 2020. [daring] malaymail.com/news/malaysia/2020/o3/16/ pm-malaysia-in-lockdown-from-wed-until-march-31all-shops-closed-except-for/1847204. [diakses pada 16 Agustus 2020].

Detiknews. 2020. “Terpapar Corona, PM Malaysia Jalani Karantina Mandiri Selama 14 Hari”. Detiknews, 23 Mei 2020. Dalam https://news.detik.com/internasional/d-5025841/ terpapar-corona-pm-malaysia-jalani-karantinamandiri-selama-14-hari. Muat turun 18 Agustus 2020.

Fukuyama, Francis. 2020. "The Pandemic and Political Order: It Takes a State". Foreign Affairs, July/August 2020. [daring] https://www.foreignaffairs.com/articles/ world/2020-06-09/pandemic-and-political-order. [diakses pada 19 Agustus 2020]. 
Husain, Nurul Huda. 2020. "Anwar syor Pakej Prihatin dibahaskan di Parlimen”. Sinar Harian, 27 Maret 2020. [daring] https://www.sinarharian.com.my/article/75946/ BERITA/Nasional/Anwar-syor-Pakej-Prihatindibahaskan-di-Parlimen. [diakses pada 18 Agustus 2020].

Ismail, Ahmad Ismadi. 2020. “26,366 individu ditahan sepanjang PKP, PKPB”. Sinar Harian 10 Jun 2020. [daring] https:// www.sinarharian.com.my/article/87126/BERITA/ Nasional/26366-individu-ditahan-sepanjang-PKP$P K P B$. [diakses pada 18 Agustus 2020].

Kementerian Kesihatan Malaysia (KKM). 2020. "Situasi Semasa Pandemik Covid-19 di Malaysia". [daring] http://covid-19. moh.gov.my/. [diakses pada 22 Agustus 2020].

Kementerian Kewangan Malaysia. 2020. "Pakej Rangsangan Ekonomi Prihatin Rakyat 2020 (PRIHATIN).” Putrajaya, 17 Maret 2020. [daring] https://www.treasury.gov.my/ pdf/Booklet-PRIHATIN-BM.pdf. [diakses pada 18 Agustus 2020].

Malay Mail. 2020. "Those who defy MCO may wind up in jail or fined, say lawyers". Malay Mail, 23 Maret 2020. [daring] https://www.malaymail.com/news/ malaysia/2020/o3/23/those-who-defy-mco-may-windup-in-jail-or-fined-say-lawyers/1849425. [diakses pada 18 Agustus 2020].

MyMtero. 2020. "PKPB berlalu, PKPP datang". MyMtero, 8 Juni 2020. [daring] https://www.hmetro.com.my/ utama/2020/o6/587252/pkpb-berlalu-pkpp-datang [diakses pada 18 Agustus 2020].

Rosly, Fahmi A., 2020. "PRIHATIN, PENJANA tak dibentang di Parlimen kerana situasi mendesak". Berita Harian Online, 13 Juli 2020. [daring] https://www.bharian.com.my/ berita/nasional/2020/07/710086/prihatin-penjanatak-dibentang-di-parlimen-kerana-situasi-mendesak. 
State Capacity and Public Trust

in Handling the COVID-19 Outbreak in Malaysia

[diakses pada 18 Agustus 2020].

Saiful Sham, Nursyazwani 2020. "COVID-19: Enhanced Movement Control Order enforced in two areas in Simpang Renggam". Astro Awani, 26 Maret 2020. [daring] http://english. astroawani.com/malaysia-news/enhanced-movementcontrol-order-two-areas-johor-midnight-235462. [diakses pada 16 Agustus 2020].

Tee, Kenneth 2020. "PM: Covid-19 shutdown extended to April 14". The Malay Mail, 25 Maret 2020. [daring] https:// www.malaymail.com/news/malaysia/2020/o3/25/ pm-covid-19-shutdown-extended-to-april-14/1850034. [diakses pada 16 Agustus 2020].

Trisha, N., Singh, Sarban, dan Nordin, Remar. 2020. "Jogger among dozens of M'sians brought to court for noncompliance". [daring] https://www.thestar.com.my/ news/nation/2020/03/31/jogger-among-dozens-ofmsians-brought-to-court-for-non-compliance. [diakses pada 18 Agustus 2020].

Warta Ekonomi. 2020. "Usai Diuji Covid-19, PM Muhyiddin Yassin Jalani Karantina Mandiri”. Warta Ekonomi.co.id. 25 Mei 2020. [daring] https://www.wartaekonomi.co.id/ read286905/usai-diuji-covid-19-pm-muhyiddin-yassinjalani-karantina-mandiri. [diakses pada 18 Agustus 2020].

Worldometers, 2020. "Covid-19, Coronavirus Pandemic". [daring] https://www.worldometers.info/coronavirus/\#countries [diakses pada 15 Agustus 2020].

World Health Organization (WHO). 2020. "What is a pandemic?". [daring] https://www.who.int/csr/disease/swineflu/ frequently_asked_questions/pandemic/en/. [diakses pada 15 Agustus 2020]. 